\title{
R-FACTOR MEDIATED $\beta$-LACTAMASE PRODUCTION BY HAEMOPHILUS INFLUENZAE
}

\author{
R. B. Sykes, M. Matthew and Cynthia H. O’Callaghan \\ Glaxo Research Ltd, Greenford, Middlesex
}

\section{Plate XLI}

Two recent reports have described $\beta$-lactamase production by antibioticresistant strains of Haemophilus influenzae (Khan et al., 1974; Williams and Cavanagh, 1974). Fifteen such strains were obtained from this country and the USA, and a study was made of the nature of the $\beta$-lactamase enzyme or enzymes produced by them and, if possible, their genetic location.

\section{MATERIALS AND METHODS \\ Organisms}

The resistant strains of $H$. influenzae were obtained from four clinical sources: Birmingham Children's Hospital (two strains), Public Health Laboratory, Stafford (four strains), Center for Disease Control, Atlanta, USA (five strains), and the Clinical Center, Md, USA (four strains).

\section{Minimum inhibitory concentrations}

Dilutions of antibiotics were prepared in nutrient agar with the addition of $5 \%$ BactoFildes Enrichment (Difco). Organisms were grown for $18 \mathrm{~h}$ in brain-heart infusion broth with $5 \%$ Bacto-Fildes enrichment (Fildes broth) in a rotary shaking incubator at $37^{\circ} \mathrm{C}$. Plates were seeded from a multipoint inoculator (Denley Instruments Ltd, Sussex), with three sizes of inoculum, $10^{3}, 10^{5}$, and $10^{7}$ cells. The MIC's were read after incubation for 18 , 24 , and $36 \mathrm{~h}$ at $37^{\circ} \mathrm{C}$ and recorded as the lowest concentrations of antibiotic preventing growth.

\section{Detection of $\beta$-lactamase}

The chromogenic cephalosporin 87/312 (O'Callaghan et al., 1972) was spotted on colonies growing on solid media. A red colour indicates the presence of a $\beta$-lactamase.

\section{Preparation of enzymes}

Organisms in Fildes' broth were grown for $18 \mathrm{~h}$ at $37^{\circ} \mathrm{C}$ in a rotary shaking incubator.

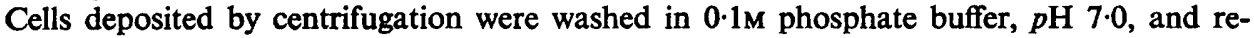
suspended in the same buffer to give a 10-times concentrated cell suspension. This was treated with an ultrasonic disintegrator (MSE Instruments Ltd) $4 \mathrm{~A}$ output for $3 \mathrm{~min}$. at $25,000 \mathrm{~Hz}$. The temperature was maintained at $4^{\circ} \mathrm{C}$ throughout the procedure. The resulting preparation was then centrifuged at $35000 \mathrm{~g}$ for $30 \mathrm{~min}$. at $4^{\circ} \mathrm{C}$ to remove cell debris. Protein determinations on the enzyme preparations were made by the method of Lowry et al. (1951).

\section{Determination of substrate profiles}

Substrate profile is defined as the relative rate of hydrolysis of a range of $\beta$-lactam substrates under standard conditions. All assays were performed iodometrically by the 
method of Perret (1954), as modified by Novick (1962). Substrates were used at a concentration of $6 \mathrm{~mm}$ and assays performed at $p \mathrm{H} 7.0$ and $37^{\circ} \mathrm{C}$. Enzyme units are defined as $\mu$ moles of substrate hydrolysed per min.

\section{Induction of $\beta$-lactamase}

Organisms grown overnight in Fildes' broth at $37^{\circ} \mathrm{C}$ were diluted 100 -fold into fresh warm broth and re-incubated for $\mathbf{4 h}$. Ampicillin was then added as an inducer at concentrations ranging from 10 to $100 \mu \mathrm{g}$ per ml. The cultures were re-incubated for another $2 \mathrm{~h}$ and $\beta$-lactamase activity was determined.

\section{Analytical isoelectric focusing of $\beta$-lactamase}

Crude preparations of sonically disintegrated organisms were focused on thin sheets of polyacrylamide gel containing $p \mathbf{H}$ 3.5-10 Ampholine (Awdeh, Williamson and Askonas, 1968; Salaman and Williamson, 1971). Samples were applied near the anode as drops of liquid on the surface of the gel. Focusing was performed at $100-400 \mathrm{~V}$ for $40 \mathrm{~h}$. The final $p \mathrm{H}$ gradient was read at intervals of $0.5 \mathrm{~cm}$ from the cathode to the anode with a miniature

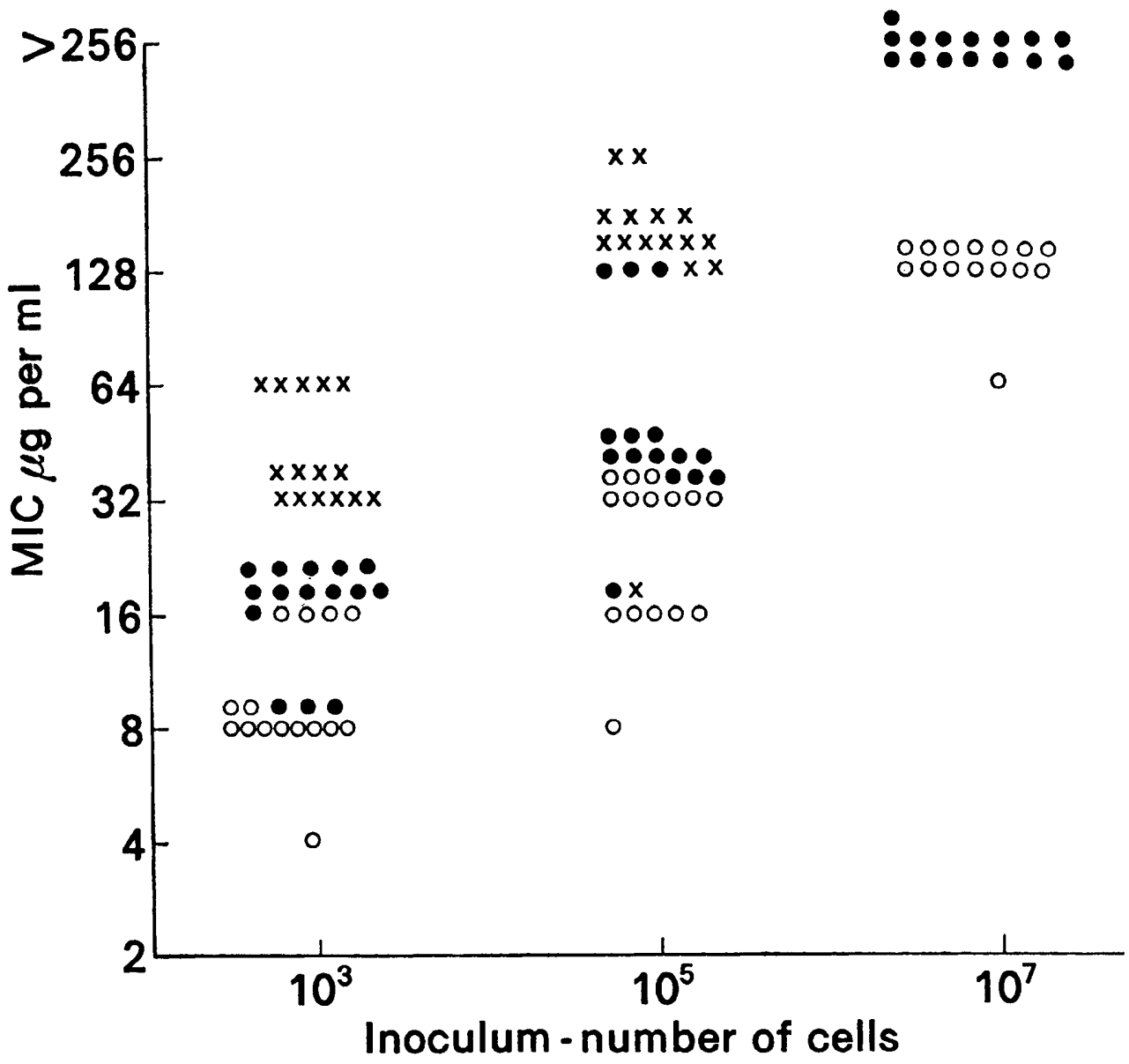

Fig. 1.-MIC of ampicillin for 15 strains of Haemophilus influenzae at three inoculum sizes after 18 $(0), 24(0)$, and $36(x)$ hours' incubation. 
flat-ended combined glass electrode (Pye Unicam 403.30 M8 EO7). Bands with $\beta$-lactamase activity were detected by damping the surface of the gel with the chromogenic cephalosporin $87 / 312(0.5 \mathrm{mg}$ per $\mathrm{ml}$ in $0.1 \mathrm{M}$ phosphate, $p \mathrm{H} \mathrm{7.0)}$. This substrate is yellow, but becomes pink when the $\beta$-lactam bond is broken, so that focused bands with $\beta$-lactamase activity appear pink on a yellow background. Photographs were taken on Kodalith Ortho film with transmitted light, and a Wratten green filter. The film was processed in phenidone-hydroquinone developer for $5 \mathrm{~min}$. at $21^{\circ} \mathrm{C}$.

\section{Immunoisoelectric focusing}

With a perspex former, troughs were set into the sheet of polyacrylamide gel on which the samples were focused. After addition of antiserum to the troughs, the gel was incubated at $4^{\circ} \mathrm{C}$ in a humid atmosphere for 7 days to allow precipitin arcs to form. These were detected by means of cephalosporin $87 / 312$.

\section{Transferability of $\beta$-lactamase genes}

This was assessed by mating experiments in which the potential donor and recipient cultures were grown together and resistant colonies of the latter were isolated by selection. For the $H$. influenzae- $H$. parainfluenzae mating, 6-h bacterial cultures of both organisms in Fildes' broth were added to fresh broth in a ratio of $1: 1$. Mating mixtures were incubated statically at $37^{\circ} \mathrm{C}$ for $18 \mathrm{~h}$ and plated on nutrient agar containing yeast extract $5 \%$ and ampicillin $50 \mu \mathrm{g}$ per ml. For the $H$. influenzae-Escherichia coli mating the same procedure was followed, but this time the organisms were added in the ratio of $10: 1(H$. influenzae/ $E$. coli). After incubation, the mating mixtures were plated on to nutrient agar containing ampicillin $50 \mu \mathrm{g}$ per $\mathrm{ml}$.

\section{ResulTS}

\section{Antibiotic resistance}

All the strains of $H$. influenzae showed high levels of resistance to ampicillin. From fig. 1 it can be seen that the resistance varied considerably with changes in inoculum size and time of incubation. Production of $\beta$-lactamase was detected in all the strains when they were tested with the chromogenic substrate.

\section{Enzyme activity and substrate profiles}

All enzyme preparations produced an identical substrate profile when tested against seven $\beta$-lactam substrates (table). The enzymes showed strong hydrolytic activity against penicillin $\mathrm{G}$, ampicillin, and cephaloridine but had

\section{TABLE}

Substrate profile of $\beta$-lactamases produced by the resistant strains of Haemophilus

\begin{tabular}{lccccccc}
\hline \multicolumn{8}{c}{ Relative rate of hydrolysis of indicated substrate } \\
\hline Pen. G & Amp. & Carb. & Meth. & Cet. & Cer. & Cex. \\
\hline $100^{*}$ & 160 & 15 & $<5$ & 10 & 140 & $<5$ \\
\hline
\end{tabular}

Pen. $\mathbf{G}=$ benzylpenicillin; Amp. = ampicillin; Carb. = carbenicillin; Meth. = methicillin; Cet. $=$ cephalothin; Cer. = cephaloridine; Cex. = cephalexin .

* Arbitrary value of 100 for the rate of hydrolysis of benzylpenicillin. 
little effect on methicillin or cephalexin. The breakdown of cephalothin and of carbenicillin was intermediate. All strains produced 0.05-0.1 enzyme units per $\mathrm{mg}$ of protein. Induction of enzyme activity was not observed.

The substrate profile of the haemophilus $\beta$-lactamase suggested that this enzyme was the same or similar to the type IIIa $\beta$-lactamase often produced by $\mathrm{R}$-factor-carrying strains of $E$. coli, e.g., $E$. coli $\mathrm{R}_{\mathrm{TEM}}$ (Richmond and Sykes, 1973).

\section{Isoelectric focusing}

Isoelectric points of six haemophilus-enzyme preparations and enzymes from $E$. coli $\mathrm{R}_{\mathrm{TEM}}$ (Datta and Richmond, 1966), E. coli $\mathrm{R}_{\mathrm{GN} 238}$ (Egawa, Sawai and Mitsuhashi, 1967) and E. coli RPI (Sykes et al., 1972), were determined by analytical isoelectric focusing. Fig. 2 shows the haemophilus enzymes to have isoelectric points identical with those of the $\beta$-lactamase produced by $E$. coli $\mathbf{R}_{\mathrm{TEM}}$. The immunoisoelectric focusing picture (fig. 3) shows the two enzyme types to be immunologically identical.

\section{Genetic transfer}

Because the $E$. coli $\mathbf{R}_{\text {TEM }} \beta$-lactamase is always $\mathbf{R}$-factor mediated (Richmond and Sykes, 1973), experiments were performed to transfer the $\beta$-lactamase gene from the resistant strains of $H$. influenzae. Three strains of $H$. parainfluenzae (fresh clinical isolates) and $E$. coli strain W3110 (Sykes and Richmond, 1970) were used as recipient strains in mating experiments with two $H$. influenzae donor strains. Transfer of $\beta$-lactamase production was achieved from both donor strains to the $H$. parainfluenzae recipients (fig. 4). Some transfer was observed to the $E$. coli strain but the transferred factor was highly unstable in it.

\section{Discussion}

Until recently, strains of $H$. influenzae have been regarded as devoid of $\beta$-lactamase and almost universally have been found to be sensitive to ampicillin, which has established itself as a treatment of choice for many infections due to the organism. The recent emergence, almost concurrently in several parts of the world, of strains that produce a high level of $\beta$-lactamase has thus aroused interest. Our investigation has confirmed that in 15 strains examined, resistance to $\beta$-lactam antibiotics was associated with the production of a $\beta$-lactamase. All the strains produced the same type of $\beta$-lactamase, and we find that this is of type IIIa, similar to that from $E$. coli $\mathrm{R}_{\mathrm{TEM}}$.

Immunological identity with the $E$. coli $\mathrm{R}_{\text {TEM }}$ enzyme, and its transferability, suggest that the $\beta$-lactamase gene carried by strains of $H$. influenzae may have been acquired from R-factor carrying strains of $E$. coli. The results of DNA hybridisation studies may furnish evidence of this.

A substance that is not susceptible to attack by $\beta$-lactamase of type IIIa seems to be required for the treatment of infections by $H$. influenzae that produce the enzyme. 
$\beta$-LACTAMASE OF HAEMOPHILLUS

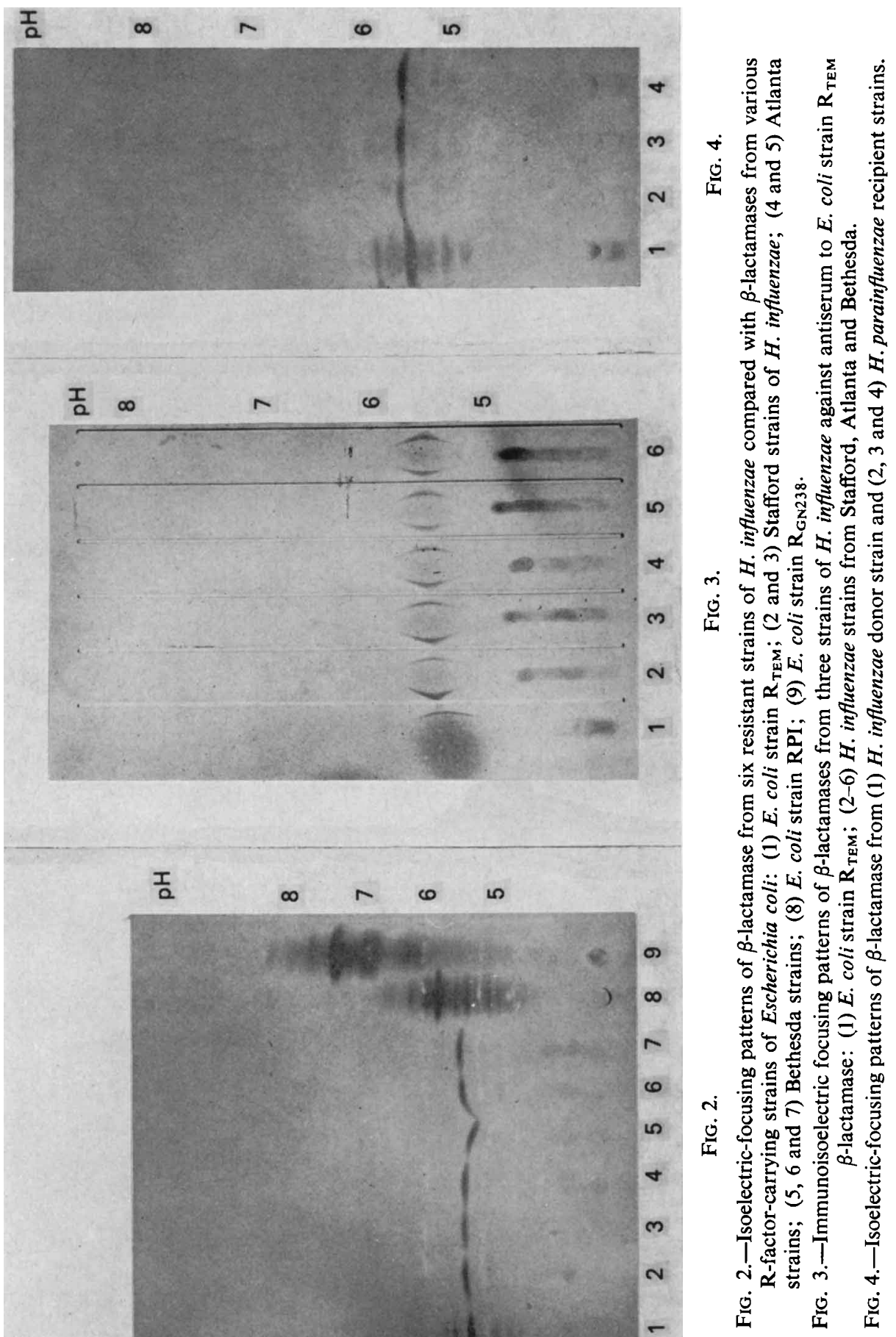




\section{SUMMARY}

Production of $\beta$-lactamase by 15 strains of Haemophilus influenzae has been investigated. All the strains produce a constitutive $\beta$-lactamase, which readily hydrolyses penicillin G, ampicillin, and cephaloridine. The $\beta$-lactamase produced by these strains is indistinguishable from the type-IIIa enzyme commonly found in strains of Escherichia coli. The $\beta$-lactamase gene has been transferred from the enzyme-producing strains of Haemophilus to strains of $H$. parainfluenzae and a strain of $E$. coli.

We thank Dr P. Cavanagh for the strains of $H$. influenzae and $H$. parainfluenzae.

\section{REFERENCES}

Awdeh, Z. L., Williamson, A. R. AND Askonas, B. A. 1968. Isoelectric focusing in polyacrylamide gel and its application to immunoglobulins. Nature, Lond., 219, 66.

DATTA, N. AND RICHMOND, M. H. 1966. The purification and properties of a penicillinase whose synthesis is mediated by an R factor in Escherichia coli. Biochem. J., 98, 204.

Egawa, R., SawaI, T. AND Mitsuhashi, S. 1967. Drug resistance of enteric bacteria. XII. Unique substrate specificity of penicillinase produced by $\mathrm{R}$ factors. Jap. J. Microbiol., 11, 173.

Khan, W., Ross, S., Rodriguez, W., Controni, G. and Saz, A. K. 1974. Haemophilus influenzae type B resistant to ampicillin. Report of two cases. J. Am. med. Ass., 229, 298.

Lowry, O. H., Rosebrough, N. J., Farr, A. L. ANd Randall, R. J. 1951. Protein measurement with the Folin phenol reagent. J. biol. Chem., 193, 265.

Novick, P. R. 1962. Staphylococcal penicillinase and the new penicillins. Biochem. J., 83, 229.

O’Callaghan, C. H., Morris, A., Kirby, S. And Shingler, A. H. 1972. Novel method for detection of $\beta$-lactamases by using a chromogenic cephalosporin substrate. Antimicrob. Agents Chemother., 1, 283.

Perret, C. J. 1954. Iodometric assay of penicillinase. Nature, Lond., 174, 1012.

RichmoND, M. H. AND SYKes, R. B. 1973. The $\beta$-lactamases of Gram-negative bacteria and their possible physiological role. Adv. Microb. Physiol., 9, 31.

Salaman, M. R. AND Williamson, A. R. 1971. Isoelectric focusing of proteins in the native and denatured states. Biochem. J., 122, 93.

SYKES, R. B. AND RICHMOND, M. H. 1970. Intergeneric transfer of $\beta$-lactamase gene between Pseudomonas aeruginosa and Escherichia coli. Nature, Lond., 226, 952.

Sykes, R. B., Grinsted, J., Ingram, L. C., SAUnders, J. R. AND Richimond, M. H. 1972. Some properties of $\mathbf{R}$ factors isolated from Pseudomonas aeruginosa. In Bacterial plasmids and antibiotic resistance, edited by V. Krćmery, L. Rosival and T. Watanabe, Berlin, p. 27.

Williams, J. D. and Cavanagh, P. 1974. Ampicillin resistant Haemophilus influenzae meningitis. Lancet, 1, 864. 